\title{
EFFECT OF PROCESSING CONDITIONS ON PROPERTIES OF POMEGRANATE SYRUP
}

\author{
Amira A. Hassan", M.R. Abd El-Mageed, F.H. Badr and G. Abdulla \\ Food Sci. Dept., Fac. Agric., Zagazig Univ., Egypt
}

\begin{abstract}
Pomegranate juice and syrup has gained great importance due to its health properties and consequently is now a highly demanded product. Effect of processing conditions on the quality of pomegranate syrup was evaluated. Citric acid, sodium benzoate, arabic gum and pomegranate peel extract were mixed with the pomegranate juice. The juice was concentrated until $42^{\circ}$ Brix. Sugar was added to the concentrated juice in different manners (cold method, semi-hot method and hot method) to increase the syrup concentration to $62^{\circ}$ Brix. Syrup samples were stored at room temperature for three months. Chemical composition, vitamin C, total phenolic content, antioxidant activity, colour and sensory evaluation of pomegranate syrup were determined during the storage period. Results showed that the total phenolic content (TPC) of pomegranate syrup ranged from 223.33 to $293.33 \mathrm{mg}$ gallic acid/g sample. Antioxidant activity and TPC decreased gradually during the storage period. Obvious changes in $\mathrm{L}^{*}, \mathrm{a}^{*}$ and $\mathrm{b}^{*}$ values of pomegranate syrup were noticed, confirming the degradation of visual colour components of the syrup during the storage period. Sensory evaluation revealed that pomegranate syrup prepared with cold method was the most accepted while that prepared by hot method was the least preferred.
\end{abstract}

Key words: Pomegranate syrup, pomegranate juice, concentration.

\section{INTRODUCTION}

Pomegranate is considered as one of the oldest fruits and one of the earliest to appear in human diet and belongs to the Punicaceae family. It is native to southwest Asia and has been cultivated over the whole Mediterranean region of Asia, Africa and Europe. In particular, its successful adaptation to the Mediterranean climate has produced a wide diffusion in various countries thus originating several local genotypes along the centuries. Pomegranate is widely cultivated throughout Afghanistan, Algeria, Armenia, Azerbaijan, Iran, Iraq, India, Pakistan, Syria, Turkey and Egypt (Hassan et al., 2014). Egypt total production of pomegranate was estimated with 64574 tons in 2011 according to statistics of the Egyptian Ministry of Agriculture (Central Administration of Agricultural Extension, 2014).

\footnotetext{
* Corresponding author: Tel. : +201126077247
}

E-mail address: miroahmed202@gmail.com
Pomegranate fruits can be eaten fresh or in the form of processed products such as single strength juices, jellies, juice concentrates, jams, marmalades, minimally processed pomegranate arils, frozen arils, refrigerated arils, arils in syrup, candied arils, arils in brandy and in vinegar, carbonated beverages, pomegranate wine, and pomegranate syrup, etc. The processed products such as juice, concentrate, syrup and jelly were highly acceptable because of their nutritive and dessert qualities and palatability (Dhumal et al., 2014).

Pomegranate fruits are rich source of carbohydrates, minerals, crude fibers, and various active compounds, such as vitamin C, and certain phenolic compounds as punicalagin, ellagic acid, gallotannins and anthocyanins. The natural antioxidants of pomegranate can protect humans against the oxidative stress and reduce consequently of chronic diseases and prevent 
disease progression (Lansky and Newman, 2007; Zaouay et al., 2012).

It has been reported that pomegranate fruits were used in folkloric medicine as a treatment for many diseases such as diarrhea, parasitic worm infections, urinary tract infections and kidney stones (Sudheesh and Vijayalakshmi, 2005). Several additional studies have demonstrated that pomegranate juice and concentrate slow bacterial growth and inhibit bacterium-induced toxins (Braga et al., 2005).The therapeutic effects of pomegranate fruit, peel and juice as powerful antioxidants and anti-inflammatory substances that include polyphenols and tannins has been reported (Aviram and Dornfeld, 2001; Aviram et al., 2002; Kim et al., 2002; Afaq et al., 2005; Gasemian et al., 2006).

The effect of processing, such as pasteurization, clarification, concentration, and dehydration effects on pomegranate juice bioactive compounds have been reported (Mena et al., 2014). Pasteurization has been shown to decrease anthocyanin content based on pomegranate cultivar and anthocyanin type (Vegara et al., 2013). Clarification, using chemical agents and filtration processes, is used to remove cloud from juices to improve colour, flavour, and storage stability. Clarification methods have displayed differences in levels of phenolic removal, for example gelatin showed a greater reduction of total phenolic while polyvinyly polypyrrolidone (PVPP) had a greater effect on anthocyanin reduction (Alighourchi et al., 2013). Also, microfiltration have a greater reduction in anthocyanin content than the use of chemical agents (Vardin and Fenercioglu, 2003; Alighourchi et al., 2008; Turfan et al., 2011 ; Anderson et al., 2015).

Despite the great importance of pomegranate derived products, the industrial processing of pomegranate is limited due to peeling difficulties and lack of technological development for industrial processing of pomegranate (LópezRubira et al., 2005).

The aim of this study was to extend the commercial shelf life of pomegranate products by producing pomegranate syrup with best properties and evaluate the effect of processing conditions on the properties of pomegranate syrup.

\section{MATERIALS AND METHODS}

\section{Materials}

About $50 \mathrm{~kg}$ fresh pomegranate fruits (Punica granatum L.) of the Manfaloty cultivar grown in Egypt were obtained from El-Obor market. Sugars, citric acid, sodium benzoate and arabic gum were obtained from Zagazig local market.

\section{Preparation of juice}

The fruits were washed, damaged fruits were discarded. Each fruit was cut in two halves and arils were manually separated and the remaining carpellar membranes were removed. Pomegranate arils were used for juicing by using juice Extractor (Molenix). The juice was then filtered through cheese cloth (Dhumal et al., 2014).

\section{Preparation of pomegranate peel extracts}

Pomegranate peel was dried by hot air at $45^{\circ} \mathrm{C}$ until constant weight. The dried pomegranate peels were ground into powder using a grinder (Moulinex, France) and sieved through a 60 mesh screen until fine powder was obtained. About $100 \mathrm{~g}$ of pomegranate peel powder was extracted according to the method of Sanbongi et al. (1998) with some modifications. Pomegranate peel powder was suspended in ethanol $70 \%(W / V)$ at ratio of $1: 10$. The mixture was stirred with magnetic stirrer overnight at ambient temperature $\left(30^{\circ} \mathrm{C}\right)$ and filtered through Whatman No.1 filter paper. The solvent was evaporated by rotary evaporator (Buchi Waterbath B-480 with Buchi Rotavapor R-124) at $45^{\circ} \mathrm{C}$ to obtain the crude extract. The yield was $100 \mathrm{ml} / 70 \mathrm{~g}$ pomegranate peel powder. The extract was kept by freezing.

\section{Preparation of pomegranate syrup}

Citric acid (0.3 g/100 g sugar), sodium benzoate $(0.1 \mathrm{~g} / 100 \mathrm{ml})$, arabic gum $(3 \mathrm{~g} / 100 \mathrm{ml})$ and pomegranate peel extract $(1 \mathrm{ml} / 100 \mathrm{ml})$ were mixed with the extracted pomegranate juice (16 ${ }^{\circ}$ Brix). The juice was concentrated at $60^{\circ} \mathrm{C}$ by rotary evaporator (BuchiWaterbath B480 with BuchiRotavapor R-124) until $42^{\circ}$ Brix. The concentrated juice was divided into three batches (A, B and C). Sugar was added to the all syrup batches in different manners (A: cold 
method; B: semi-hot method; C: hot method) according to Bassiuony (1994). Cold method: the sugar (105g) was dissolved in the concentrated juice at room temperature until $62^{\circ}$ Brix. Semi-hot method: the specified amount of sugar (105g) was dissolved in a quantity of water (equal to $1 / 3$ volume of the concentrated juice) then brought to boiling $100^{\circ} \mathrm{C}$. The hot sugar solution was allowed the cool to $45^{\circ} \mathrm{C}$. Then the concentrated juice was added to sugar solution to obtain final TSS of $62^{\circ}$ Brix. Hot method: the sugar was dissolved in the concentrated juice at $100^{\circ} \mathrm{C}$ in water bath to obtain pomegranate syrup of $62^{\circ}$ Brix. Syrup samples were stored at room temperature for three months.

\section{Analytical methods}

The total soluble solids were measured by hand held refractometer (Bellingham and Stanley Ltd., UK). The $\mathrm{pH}$ value of juice and syrup was measured using $\mathrm{pH}$ meter type 3320 Jenway LTD. (FelstedDanmow Essex CM63 IB, UK). Titratable acidity (as citric acid), total, reducing and non-reducing anhydrous sugars and ash were determined according to the method described in AOAC (2005).

\section{Determination of total phenolic content (TPC)}

Total phenolic contents of pomegranate juice and syrup were measured by Folin-Ciocalteu method according to Singelton et al. (1999) using gallic acid as standard at wavelength 760 $\mathrm{nm}$. The results were expressed as mg gallic acid/ $100 \mathrm{ml}$ sample.

\section{Determination of free radical scavenging activity (DPPH Assay)}

The free radical scavenging activity using the 1,1-diphenyl-2-picrylhydrazil (DPPH) reagent was determined according to Cuendet et al. (1997) with slight modifications. Fifty microliters of pomegranate juice or syrup was added to $1 \mathrm{ml}$ of $0.2 \mathrm{mM}$ of methanolic DPPH solution (0.0078 g of pure DPPH (Mw = 394.32 $\mathrm{g} / \mathrm{mol}$ ) in $10 \mathrm{ml}$ methanol). The solutions were vigorously shaken and left at room temperature in the dark. After 45 min of incubation in dark at room temperature, the absorbance was measured at $517 \mathrm{~nm}$ against a blank (methanol). The inhibition of DPPH free radicals (I\%) was calculated as follows:

$(\mathrm{I} \%)=\left[\left(\mathrm{A}_{517 \mathrm{~nm}}\right.\right.$ blank- $\mathrm{A}_{517 \mathrm{~nm}}$ sample $) / \mathrm{A}_{517 \mathrm{~nm}}$ blank $] \times 100$

\section{Colour measurement}

Colour values of pomegranate juice and syrup $\left(\mathrm{L}^{*}, \mathrm{a}^{*}\right.$ and $\left.\mathrm{b}^{*}\right)$ were measured using Hunter Lab colour analyzer (Hunter Lab Colour Flex EZ, USA) according to Rao et al. (2011). The $L^{*}$ value (lightness index scale) ranges from 0 (black) to 100 (white) while, $\mathrm{a}^{*}$ value indicates the redness $(+a)$ or greenness $\left(-a^{*}\right)$ and the $b^{*}$ value refers to the yellowness $(+b)$ or blueness $\left(-b^{*}\right)$.

\section{Sensory evaluation}

Pomegranate syrup was reconstituted to the original strength $\left(16^{\circ}\right.$ Brix $)$ by water. All samples were subjected to sensory evaluation for colour, taste, flavour and overall acceptability. The juice samples were introduced to 10 panelists (Staff members of Food Science Department, Faculty of Agricultural, Zagazig University, Egypt) immediately after juice preparation. The samples were sensory evaluated using hedonic scale of 1 to 9 point, where $(1$ =dislike extremely, $2=$ dislike very much, $3=$ dislike moderately, $4=$ dislike slightly, $5=$ neither like nor dislike, $6=$ like slightly, $7=$ like moderately, 8 , like very much, $9=$ like extremely) (Matta et al., 2005).

\section{RESULTS AND DISCUSSION}

\section{Chemical Characteristics of Pomegranate Juice and Syrup}

Table 1 shows the chemical composition of pomegranate juice and syrup (cold method). Total soluble solids (TSS) of syrup (62 $2^{\circ}$ Brix) was found to be higher than that of juice $\left(16^{\circ}\right.$ Brix) due to sugar addition during processing. The $\mathrm{pH}$ of syrup (3.26) was lower than that found in juice (3.45) and concentrated juice (3.50) while, total titratable acidity of syrup (2.71\%) was found to be higher than that of juice $(0.88 \%)$. This may be related to the presence of citric acid. The ash content of syrup $(2.73 \%)$ was found to be higher than that of juice $(0.62 \%)$ because of the presence of peel. The ascorbic acid content of the juice $(68.0 \mathrm{mg} /$ 
Table 1. Chemical characteristics of pomegranate juice and syrup

\begin{tabular}{lccccccc}
\hline Sample & $\begin{array}{c}\text { TSS } \\
\left({ }^{\circ} \text { Brix) }\right.\end{array}$ & $\begin{array}{c}\text { pH } \\
\text { Total titratable } \\
\text { acidity } \\
\text { (\% citric acid) }\end{array}$ & $\begin{array}{c}\text { Ash } \\
\mathbf{( \% )}\end{array}$ & $\begin{array}{c}\text { Ascorbic } \\
\text { acid } \\
(\mathbf{m g} / \mathbf{1 0 0 m l})\end{array}$ & $\begin{array}{c}\text { Reducing Total phenolic } \\
\text { sugars } \\
\mathbf{( \% )}\end{array}$ & $\begin{array}{c}\text { content } \\
\text { (mg/g) }\end{array}$ \\
\hline Juice & 16 & 3.45 & 0.88 & 0.62 & 68.0 & 12.40 & 2.57 \\
Syrup (cold method) & 62 & 3.26 & 2.71 & 2.73 & 20.21 & 56.74 & 293.33 \\
\hline
\end{tabular}

$100 \mathrm{ml}$ ) was higher than that of the syrup (20.21 $\mathrm{mg} / 100 \mathrm{ml}$ ) because of the oxidation and heat effects during the concentration process (Paul and Ghosh, 2012). Logically, reducing sugars of the syrup (56.74\%) was found to be higher than that of juice (12.40\%). Total phenolic content of the syrup (293.33 mg/g) was found to be higher than that of juice $(2.57 \mathrm{mg} / \mathrm{g})$ because of the peels presence which has higher antioxidant compounds. These results are in close agreement with Yousefi et al. (2012) and Fazaeli et al. (2013).

\section{Effect of Storage Period on Total Phenolic Content (TPC) on Pomegranate Syrup}

Total phenolic content of pomegranate syrup was measured during the storage period of 3 months. Table 2 shows that the syrup made by cold method had better total phenolic contents than semi-hot and hot methods. The total phenolic content ranged from 223.33 to 293.33 $\mathrm{mg}$ gallic acid/g sample. It was noticed that TPC content decreased gradually during the storage period. These results are in accordance with Chalfoun-Mounayar et al. (2012) who measured the total polyphenols content of pomegranate molasses, compared to fresh pomegranate juice, being 252.28 and $79.49 \mathrm{mg}$ of gallic acid equivalent/l, respectively. Total phenolic content revealed that pomegranate syrup prepared with cold method was the highest for the non-use of heat.

\section{Effect of Storage Period on Free Radical Scavenging Activity (DPPH assay)}

Antioxidant activity of pomegranate syrup was measured using DPPH method during the storage period and the results are illustrated in
Fig. 1. Antioxidant activity was affected by the storage period and also with the processing method. Gradual decrease in the antioxidant activity of all syrup samples was noticed during the storage period. Similar to the decrease in TPC content, cold method gave the highest antioxidant activity values followed by the semihot and hot methods. Yousefi et al. (2012) investigated the effect of heating method on the degradation of antioxidant activity and they stated that applying microwave instead of conventional heating method could conserve better the antioxidant activity of pomegranate juice. Fazaeli et al. (2013) reported that anthocyanin degradation and consequently decrease in antioxidant activity were more pronounced in rotary evaporation compared to microwave heating method. These results are in harmony with Mousavinejad et al. (2009).

\section{Effect of Storage Period on Colour Attributes of Pomegranate Syrup}

The colour of fruit juices and concentrates is considered an important factor that attracts the consumer and has a remarkable influence on his acceptance and quality evaluators (Turfan et al. 2011). The colour values of the fresh pomegranate juice were $9.25\left(\mathrm{~L}^{*}\right), 6.46\left(\mathrm{a}^{*}\right)$ and $0.21\left(\mathrm{~b}^{*}\right)$. The changes in the colour values $\left(\mathrm{L}^{*}, \mathrm{a}^{*}\right.$, and $\mathrm{b}^{*}$ ) of pomegranate syrup during the storage period are illustrated in Fig. 2. In general, all colour values were gradually decreased during the storage period. The method of processing significantly affected the colour values of pomegranate syrup. Cold method had the highest pomegranate syrup colour values while, hot method had the lowest. There were obvious changes in $\left(L^{*}, a^{*}\right.$, and $\left.b^{*}\right)$ values, confirming 
Table 2. Effect of storage period on total phenolic content of pomegranate syrup

\begin{tabular}{cccc}
\hline \multirow{2}{*}{$\begin{array}{c}\text { Storage period } \\
\text { (week) }\end{array}$} & \multicolumn{3}{c}{ TPC (mg gallic acid/g sample) } \\
\cline { 2 - 4 } & Cold method & Simi-hot method & Hot method \\
\hline 0 & 293.33 & 289.73 & 284.33 \\
3 & 284.33 & 271.67 & 255.00 \\
6 & 271.67 & 260.00 & 243.33 \\
9 & 263.33 & 236.67 & 235.00 \\
12 & 251.67 & 231.67 & 223.33 \\
\hline
\end{tabular}

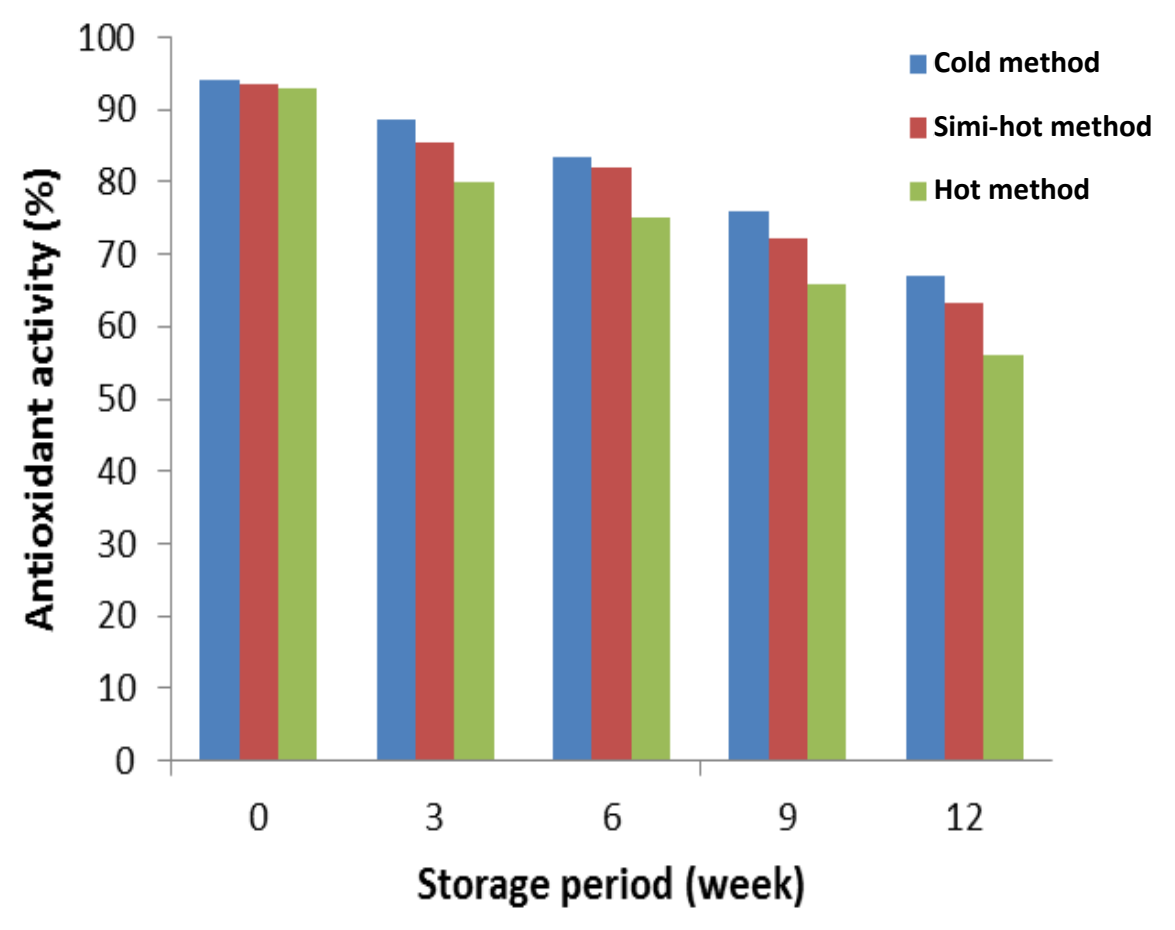

Fig. 1. Effect of storage period on antioxidant activity of pomegranate syrup 

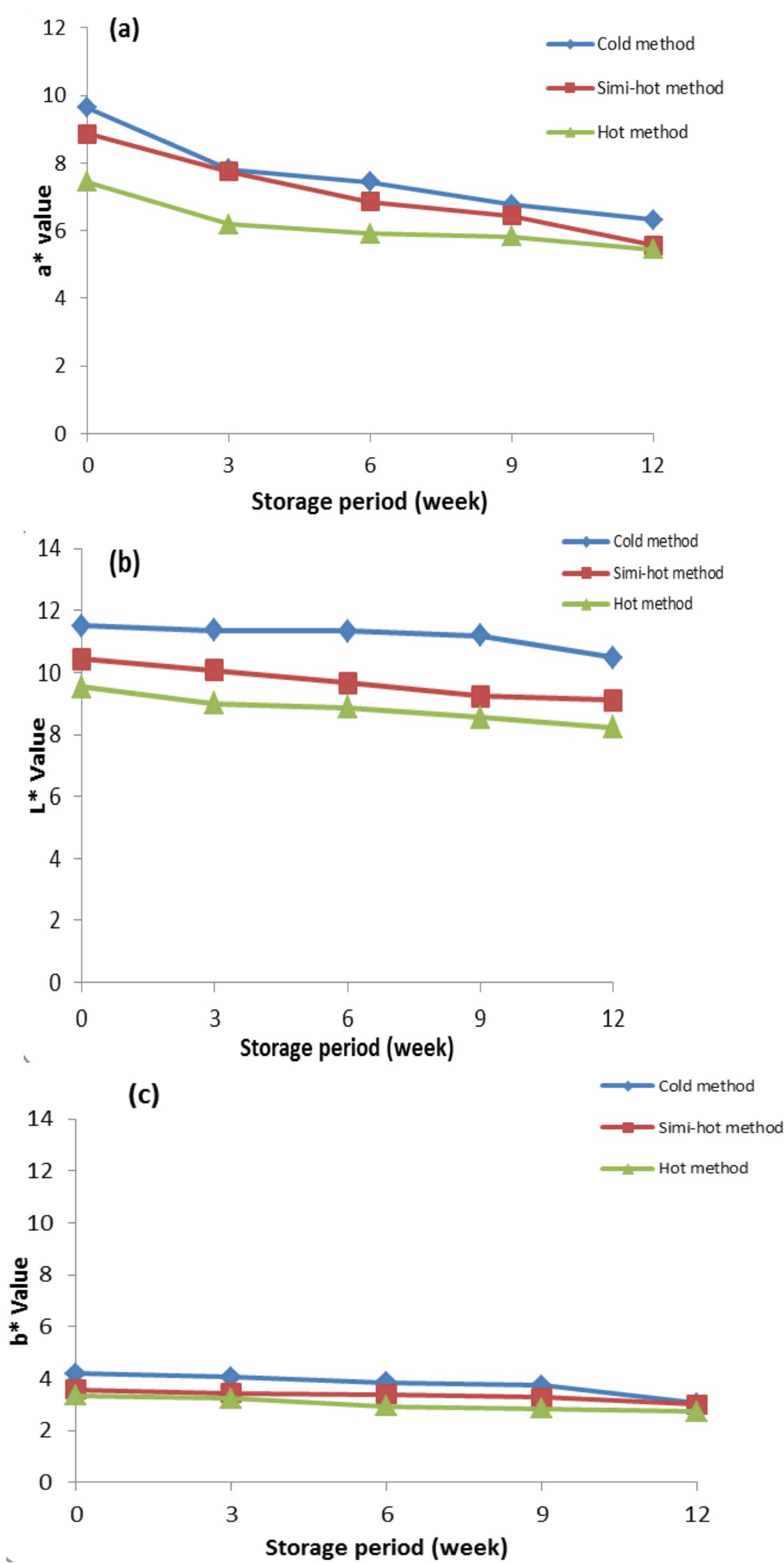

Fig. 2,a,b,c. Effect of storage period on colour values of pomegranate syrup 

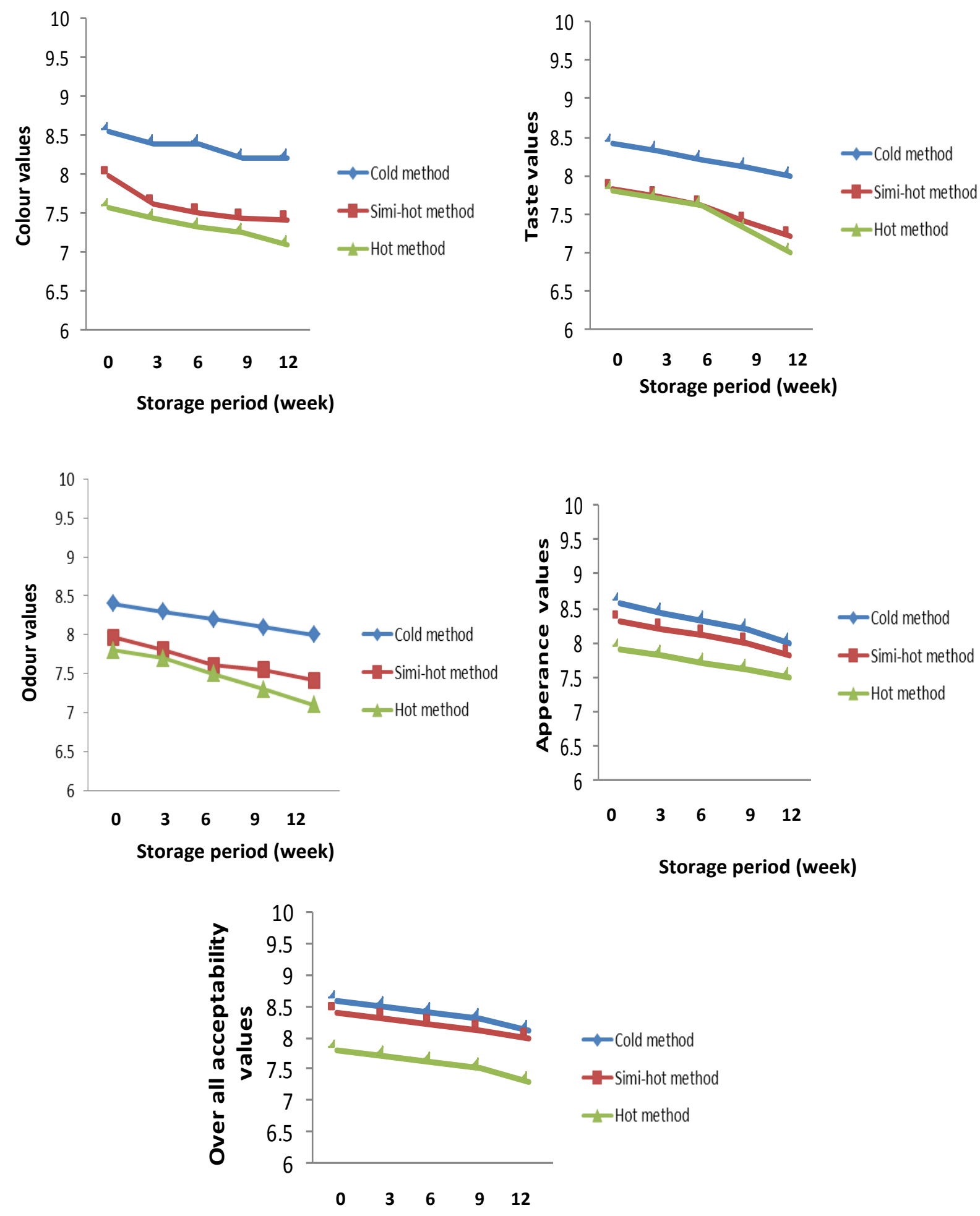

Storage period (week)

Fig. 3. Effect of processing method on sensory evaluation of pomegranate syrup 
the degradation of visual colour components of the syrup during the storage period. Turfan et al. (2011) reported that the reduction in $a^{*}$ value of pomegranate concentrate, as an indicator for the degradation of anthocyanin pigments, normally occurs due to heat damages during thermal processing, nonenzymatic browning reactions and polymerization of anthocyanins with other phenolic compounds. Khajehei et al. (2014) found that the $a^{*}$ value of pomegranate juice which was concentrated by rotary vacuum evaporator and by heating at atmospheric pressure reduced by about 71 and $74 \%$ in average, compared to the a value of the initial pomegranate juice, respectively. Colour parameters were decreased at the end of the storage period. These data are in agreement with those obtained by Yousefi et al. (2012).

\section{Effect of Storage Period on Sensory Evaluation of Pomegranate Syrup}

Sensory evaluation plays significant role in measuring characteristics and acceptability of foods and food products. The results of sensory evaluation (colour, taste, odoure, appearance and overall acceptability) of pomegranate syrup immediately after preparation are shown in Fig. 3. Processing method significantly affected the sensory quality of pomegranate syrup. Results of the sensory evaluation by the panelists showed that the pomegranate syrup prepared with cold method was the most accepted while that prepared by hot method was the least preferred. As for colour, cold method had the highest score recorded 8.39 while hot method had the lowest (7.58). Pomegranate syrup prepared with cold and semi-hot methods had higher overall acceptability than that prepared with hot method. Thermal processing and concentration process are the most commonly used preservation technique to extend the shelf-life of juices. However, this process may have adverse effects on sensory and nutritional values of juices (Plaza et al., 2006).

\section{Conclusion}

The results of this study indicated that producing pomegranate syrup by the cold method is a promising product from pomegranate juice. It is characterized by highly acceptable colour and antioxidant.

\section{REFERENCES}

Afaq, F., M. Saleem, C.G. Krueger, J.D. Reed and H. Mukhtar (2005). Anthocyanin- and hydrolyzable tannin-rich pomegranate fruit extract modulates MAPK and NF-kappaB pathways and inhibits skin tumorigenesis in CD-1 mice. Int. J. Cancer, 113: 423-433.

Alighourchi, H., M. Barzegar and S. Abbasi (2008). Anthocyanins characterization of 15 Iranian pomegranate (Punica granatum L.) varieties and their variation after cold storage and pasteurization. Eur. Food Res. Technol., 227: 881-887

Alighourchi, H.R., M. Barzegar, M.A. Sahari and S. Abbasi (2013). Effect of sonication on anthocyanins, total phenolic content, and antioxidant capacity of pomegranate juices. Int. Food Res. J., 20 (4): 1703-1709.

Anderson, E., K. Koppel and E. Chambers (2015). Consumer evaluation of processing variants of pomegranate juice. Beverages, 1 : 3-16.

AOAC (2005). Official Methods of Analysis of the Association of Official Analytical Chemists, $18^{\text {th }}$ Ed., AOAC Int., Arlington, Virginia, USA.

Aviram, M. and L. Dornfeld (2001). Pomegranate juice consumption inhibits serum angiotensin converting enzyme activity and reduces systolic blood pressure. Atherosclerosis, 158: 195-198.

Aviram, M., L. Dornfeld, M. Kaplan, R. Coleman, D. Gaitini, S. Nitecki, A. Hofman, M. Rosenblat, N. Volkova, D. Presser, J. Attias, T. Hayek and B. Fuhrman (2002). Pomegranate juice flavonoids inhibit LDL oxidation and cardiovascular diseases: studies in atherosclerotic mice and in humans. Drugs Exp. Clin. Res., 28:49-62

Bassiuony, S.A. (1994). Fundamentals of Food Preservation and Processing. Zagazig Univ., Publisher, P: 402.

Braga, L.C., J.W. Shuppb, C. Cummingsb, M. Jettb, J.A. Takahashic, L.S. Carmod, E. ChartoneSouzaa and A.M.A. Nascimento (2005). 
Pomegranate extract inhibits Staphylococcus aureus growth and subsequent enterotoxin production. J. Ethnopharmacol., 96: 335-339.

Central Administration of Agricultural Extension (2014). Bulletin of pomegranate.

Chalfoun-Mounayar, A., R. Nemr, P. Yared, S. Khairallah and R. Chahine (2012). Antioxidant and weight loss effects of pomegranate molasses. J. Appl. Pharm. Sci., 2 (6): 45-50.

Cuendet, M., K. Hostettmann and O. Potterat (1997). Iridoidglucosides with free radical scavenging properties from Fagraeablume. Helvetica Chimica Acta., 80: 1144-1152.

Dhumal, S.S., A.R. Karale, S.B. Jadhav and V.P. Kad (2014). Recent advances and the developments in the pomegranate processing and utilization: A Rev. J. Agric. and Crop Sci., 1 (1) : 1 - 17.

Fazaeli, M., S. Yousefi and Z. Emam-Djomeh (2013). Investigation on the effects of microwave and conventional heating methods on the phytochemicals of pomegranate (Punica granatum L.) and black mulberry juices. Food Res. Int., 50: 568-573.

Gasemian, A., S. Mehrabian and A. Majd (2006). Peel extracts of two Iranian cultivars of pomegranate (Punica granatum L.) have antioxidant and antimutagenic activities. Pak. J. Biol. Sci., 9 : 1402-1405.

Hassan, A., A. Janbi and S.A. Al-Said (2014). The effect of technological treatments of the pasteurized juice processing on the antioxidant compounds content and the antioxidant activity of pomegranate (Punica granatum L.) fruits juice. Middle East J. Appl. Sci., 4 (2): 232-242.

Khajehei, F., M. Niakousari, M.H. Eskandari and M. Sarshar (2014). Production of pomegranate juice concentrate by complete block cryoconcentration process. J. Food Proc. Eng., 38 : 488-498.

Kim, N.D., R. Mehta, W. Yu, I. Neeman, T. Livney and A. Amichay (2002). Chemopreventive and adjuvant therapeutic potential of pomegranate (Punica granatum L.) for humanbreast cancer. Breast Cancer Res. and Treat., 71 : 203-217.
Lansky, E.P. and R.A. Newman (2007). Punica granatum L. (pomegranate) and its potential for prevention and treatment of inflammation and cancer. J. Ethnopharmacol., 109 : 177206.

López-Rubira, V., A. Conesa, A. Allende and F. Artés (2005). Shelf life and overall quality of minimally processed pomegranate arils modified atmosphere packaged and treated with UV-C. Postharvest Biol. and Technol., 37: 174-185.

Matta, Z., E.I.V. Chambers and G. Naughton (2005). Consumer and descriptive sensory analysis of black walnut syrup. J. Food Sci., 70 (9): 610-613.

Mena, P., N. Marti and C. Garcia-Viguera (2014). The impact of processing and storage on the (poly) phenolic fraction of pomegranate (Punica granatum L.) juices. Proc. and Impact on Antiox. Beverages, 18 : 173-184.

Mousavinejad, G., Z. Emam-Djomeh, K. Rezaei and M.H. Haddad-Khodaparast (2009). Identification and quantification of phenolic compounds and their effects on antioxidant activity in pomegranate juices of eight Iranian cultivars. Food Chem., 115 : $1274-$ 1278.

Paul, R. and U. Ghosh (2012). Effect of thermal treatment on ascorbic acid content of pomegranate juice. Indian J. Biotechnol., 11: 309-313.

Plaza, L., C. Sanchez-Moreno, P. Elez-Martinez, B. Ancos, O. Martin-Belloso and M.P. Cano (2006). Effect of refrigerated storage on vitamin $\mathrm{C}$ and antioxidant activity of orange juice processed by high-pressure or pulsed electric fields with regard to low pasteurization. European Food Res. and Technol., 223: 487-493.

Rao, L., H. Khizar, L. Yi, E. Karangwa, S.Q. Xia, C.S. Jia and X.M. Zhang (2011). Effect of ultrafiltration and fining adsorbents on the clarification of green tea. J. Food Eng., 102 (4): 321-326.

Sanbongi, C., N. Osakabe, M. Natsume, T. Takizawa, S. Gomi and T. Osawa (1998). Antioxidative polyphenols isolate from 
Theobromacaco. J. Agric. Chem., 46: 454457.

Singelton, V.R., R. Orthifer and R.M. LamuelaRaventos (1999). Analysis of total phenols and other oxidation substrates and antioxidants by means of Folin-Ciocalteu reagent. Methods in Enzymol., 299: 152-178.

Sudheesh, S. and N.R. Vijayalakshmi (2005). Flavonoids from Punica granatum L. potential antiperoxidative agents. Fitoterapia, 76 : 181-186.

Turfan, O., M. Türkyilmaz, O. Yemis and M. Özkan (2011). Anthocyanin and colour changes during processing of pomegranate (Punica granatum L., cv. Hicaznar) juice from sacs and whole fruit. Food Chem., 129: 1644-1651.

Vardin, H. and H. Fenercioglu (2003). Study on the development of pomegranate juice processing technology: Clarification of pomegranate juice. Nahrung., 47: 300-303.

Vegara, S., P. Mena, N. Martí, D. Saura and M. Valero (2013). Approaches to understanding the contribution of anthocyanins to the antioxidant capacity of pasteurized pomegranate juices. Food Chem., 141 : 1630 - 1636.

Yousefi, S., Z. Emam-Djomeh, S.M.A. Mousavi and G.R. Askari (2012). Comparing the effects of microwave and conventional heating methods on the evaporation rate and quality attributes of pomegranate (Punica granatum L.) juice concentrate. Food Bioprocess Technol., 5:1328-1339.

Zaouay, F., P. Mena, C. Garcia-Viguera and M. Mars (2012). Antioxidant activity and physico-chemical properties of Tunisian grown pomegranate (Punica granatum L.) cultivars. Industrial Crops and Prod., 40:81- 89.

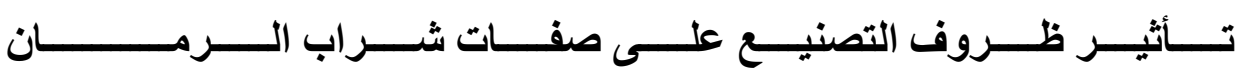

$$
\begin{aligned}
& \text { أميرة أحمد حسن - محمد رجب عبد المجيد- فريد حسن بلر - جلال عبد الله } \\
& \text { قسم علوم الأغذية ـ كلية الزر اعة - جامعة الزقازيق ـ مصر }
\end{aligned}
$$

نظراً لأهمية عصير وشر اب الرمان من الناحية الغذائية والصحية وزيادة الطلب علي المنتج فقد تم إنتاج شر اب رماب رمان

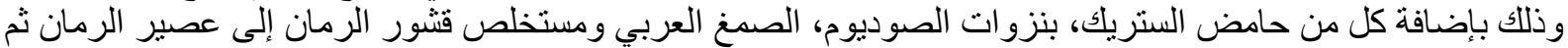

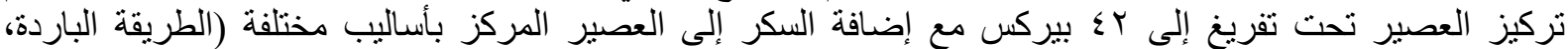

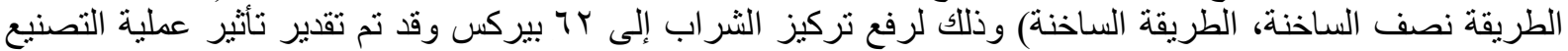

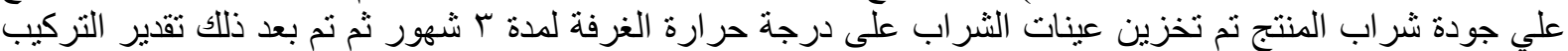

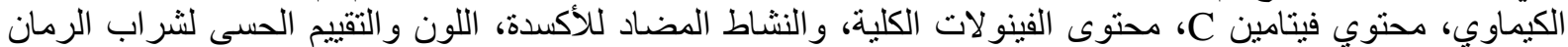

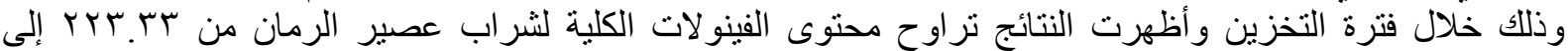

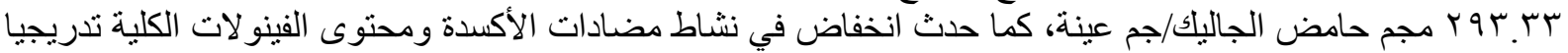

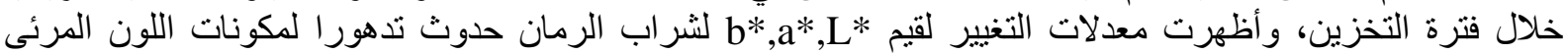

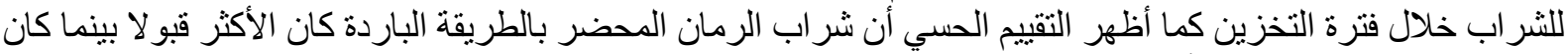

أستاذ الصناعات الغذائية - كلية الزر اعة بمشتهر - جامعة بنها. أستاذ الصناعات الغذائية المتفرغ - كلية الزر اعة - جامعة الزقازيق. 